\title{
Potential use of green algae Caulerpa lentillifera as feed ingredient in the diet of Nile tilapia Oreochromis niloticus
}

\section{Potensi penggunaan rumput laut Caulerpa lentillifera sebagai bahan baku pakan ikan nila Oreochromis niloticus}

\author{
Nadisa Theresia Putri ${ }^{1}$, Dedi Jusadi ${ }^{1 *}$, Mia Setiawati ${ }^{1}$, Mas Tri Djoko Sunarno² \\ ${ }^{1}$ Department of Aquaculture, Faculty of Fisheries and Marine Science, Bogor Agricultural University \\ Campus IPB Dramaga Bogor, West Java, Indonesia 16680 \\ ${ }^{2}$ Center for Research and Development of Freshwater Aquaculture, Jl. Sempur No.1, Bogor, West Java, Indonesia \\ *E-mail: dedidj@ipb.ac.id
}

\begin{abstract}
The high composition of import raw material of fish diet in Indonesia causes feed price expensively and should be replaced using local materials such as green macro algae. It is, therefore, this study aimed to evaluate effect of diet containing the Caulerpa lentillifera, as feed ingredient in the diet of Nile tilapia Oreochromis niloticus. This study consisted of two experiments which were $C$. lentillifera digestibility test for raw material feed for tilapia and growth performance test of tilapia. C. lentillifera digestibility test was done by using $\mathrm{Cr}_{2} \mathrm{O}_{3}$ as indicators and analysis of faecal tilapia. The second experiment is growth performance test using a completely randomised design with four diets were formulated at variuos rates of $C$. lentillifera meal of 0 (control), 10, 20, and 30\%. A number of 240 tilapia fingerlings of $3.41 \pm 0.10 \mathrm{~g}$ in mean weight were randomly stocked in 12 aquaria and fed on diet test for growth performanced of rearing period. $C$. lentillifera digestiility test result showed a good value as a raw material feed tilapia, the digestibility of $C$. lentiliifera and protein digestibility amounted to $68.81 \%$ and $86.31 \%$. Growth performance parameters showed the use of $10 \%$ and $20 \%$ is not significantly different from the control $(\mathrm{P}>0.05)$, to the final body weight, protein efficiency ratio, protein retention, specific growth rate, and feed efficiency. But, the diet test at $30 \%$ performed the lowest growth performance and feed utilization as well of tilapia fingerlings. This study, therefore, concludes that $C$. lentillifera meal could be used up to $20 \%$ in the tilapia diet.
\end{abstract}

Keywords: Caulerpa lentillifera, Nile tilapia, feed utilization, growth performance

\begin{abstract}
ABSTRAK
Tingginya jumlah bahan baku impor dalam pakan ikan di Indonesia menyebabkan harga pakan yang tinggi dan harus diganti menggunakan bahan alternatif lokal seperti makro alga. Penelitian ini bertujuan untuk mengkaji pengunaan dari pakan yang mengandung Caulerpa lentillifera sebagai bahan baku pakan ikan nila Oreochromis niloticus. Tahapan penelitian terdiri atas uji kecernaan $C$. lentillifera sebagai bahan baku dan uji kinerja pertumbuhan ikan nila. Metode uji kecernaan menggunakan $\mathrm{Cr}_{2} \mathrm{O}_{3}$ sebagai indikator pakan dan analisis feses ikan nila. Tahap penelitian kedua adalah kinerja pertumbuhan menggunakan rancangan acak lengkap dengan pakan diformulasikan dengan inklusi 0 (kontrol), 10, 20, dan 30\% tepung C. lentillifera. Ikan nila sebanyak 240 ekor, dengan berat rata-rata $3,41 \pm 0,1 \mathrm{~g}$ dibagi kedalam 12 akuarium dan diberi pakan perlakuan untuk melihat kinerja pertumbuhan. Hasil uji kecernaan $C$. lentillifera menunjukkan nilai yang baik sebagai bahan baku pakan ikan nila, yaitu kecernaan bahan sebesar $68,81 \%$ dan kecernaan protein sebesar $86,31 \%$. Parameter kinerja pertumbuhan menunjukkan perlakuan penambahan $10 \%$ dan $20 \%$ tepung $C$. lentillifera tidak berbeda nyata $(\mathrm{P}>0,05)$ dengan kontrol, yang terdiri atas: bobot tubuh akhir, pertumbuhan mutlak, protein efisiensi rasio, retensi protein, laju pertumbuhan spesifik dan efisiensi pakan. Namun, pakan perlakuan 30\% menghasilkan kinerja pertumbuhan dan efisiensi pakan yang lebih rendah pada ikan nila. Penelitian ini memberikan hasil, penggunaan tepung $C$. lentillifera dapat digunakan sampai $20 \%$ dalam pakan ikan nila.
\end{abstract}

Kata kunci: Caulerpa lentillifera, nila, pemanfaatan pakan, kinerja pertumbuhan 


\section{INTRODUCTION}

Fish and srimp feed production reached a total annual production of 1,411,000 ton (GPMT, 2015) in Indonesia in 2014. Producing such amount of feed required raw materials and Indonesian feed production mainly depends on imported raw material. Indeed, nowadays, Indonesia imports up to $70 \%$ of its raw materials, including soybean meal and white pollard. Several research were conducted to decrease the amount of imported raw materials by using local raw materials. Local raw materials that have alreary been explored for possible use and engineered in order to increase their nutritional value included lamtoro leaves, cassava (onggok singkong), cacao fruit peel, Kapok seeds, cassava peel, kopra, rubber seed, and palm oil cake (Fitriliyani, 2010; Suprayudi et al., 2012; Jusadi et al., 2013; Afebrata et al., 2014). However, the availability of these raw materials is relatively limited and still way below the required amount required to fulfill the need for imported raw materials. As a concequence of the limited availability, there is a need to search for potential raw materials within the Indonesian natural ressources to be used as raw material in fish feed. One of the natural ressources that has been used as a potential raw material is seaweed, demonstrating the vast coastal area, about 769,452 ha, that could be used to culture seaweed (Sahat, 2013).

Carrageenan content of seaweed is a limiting factor in the use of seaweed as raw material for fish feed, since the physical behavior of carrageenan can form gel or rigid (Widyastuti, 2010). A seaweed species that does not contain carageenaan is green algae Caulerpa lentillifera (Widyastuti, 2008). In addition, Murugaiyan et al. (2012) stated that green algae contain high protein compared to both red algae and brown algae. $C$. lentillifera is an algae specy that possesses amino acids contents higher than that of Sargassum polycystum dan Eucheuma cottonii (Matanjun et al., 2009). The proximat composition (dry weight) of $C$. lentillifera from Binuangeun area, Pandeglang was as follows: protein $(11.11 \%)$, ash $(44.58 \%)$, fat $(0.23 \%)$, crude fiber $(18.16 \%)$ and NFE (25.92\%). Meanwhile, the proximat composition (dry weight) of $C$. lentillifera from Takalar area revealed nutrient compositions as follows: protein $(29.16 \%)$, ash $(16.56 \%)$, fat $(0.76 \%)$, crude fiber $(7.07 \%)$ and NFE $(46.45 \%)$. C. lentiliifera seaweed can be potentially cultured due to its role as biofilter in maintaining water quality in aquaculture activities (Chaitanawisuti et al., 2011; Liu et al., 2016). As it can be observed above, C. lentiliifera has a high mineral content as other kind of seaweeds (Kut-Guroy, 2007; Matanjun et al., 2009; Natify et al., 2015; Mahasu, 2016). Macro-mineral analysis results revealed that the macro minerals with the highest concentration in $C$. lentiliifera are calcium and magnesium, while iron had the lowest micromineral concentration (Matanjun et al., 2009). Minerals are trace elements that are highly required, although in low quantity. However, high ash consumption in the feed can lead to a decrease in nutrients absorption that will in turn decrease growth (Sugiura et al., 1998).

As a result of the mentioned advantages, C. lentillifera has a potential raw material to be developed in aquafeed, since it can decrease imported raw materials use such as soybean meal and white pollard. However, the quality of a given raw material is also determined by its digestibility. Thus, the present research was aimed at evaluating the digestibility of $C$. lentillifera and its optimal quantity in tilapia feed formulation.

\section{MATERIALS AND METHODS}

\section{Research design}

The use of $C$. lentillifera as raw material in tilapia feed was carried out in series of two research using a completely randomized design. The first research was performed to determine C. lentillifera digestibility in tilapia. While the second research was performed to evaluate the effects of adding $C$. lentillifera in feed formula on tilapia growth performance. Feed formula were divided into treatments with three replicates each i.e. $0 \%$ C. lentillifera powder (as control), $10 \%$ C. lentillifera, $20 \%$ C. lentillifera, and $30 \% C$. lentillifera.

\section{Caulerpa lentillifera}

C. lentillifera seaweed was obtained from waste drainage ponds of shrimp farms in Teluk Laikang, Takalar, South Sulawesi, in January 2016. C. lentillifera seaweed was immersed in freshwater for 30 minutes and cleaned. Afterwards, C. lentillifera was dried in an oven at a temperature of $40{ }^{\circ} \mathrm{C}$ for 18 hours (to reach $7 \%$ water content), then grinded using a grinding machine. Proximate composition of $C$. lentillifera (dry weight) revealed that it contained protein (29.16\%); fat (0.76\%); carbohyfrate $(53.52 \%)$; and ash $(16.56 \%)$. 


\section{Digestibility test of feed}

C. lentillifera digestibility test was performed by mean of formulating $30 \% \mathrm{C}$. lentillifera with feed and mixed with $0.5 \%$ chromium indicator $\left(\mathrm{Cr}_{2} \mathrm{O}_{3}\right)$. The mentioned formula was compared to a reference feed following Watanabe (1988).

\section{Growth performance feed}

The composition of the growth test feed is presented in Table 1. C. lentillifera powder was used in feed formula at different percentages $(0$, $10,20$, and $30 \%)$. All of the tested feed were formulated to have a protein content of $28 \%$ and similar energy contents. Feed were processed with the same protein and energy content in all treatments. An increase in feed $C$. lentillifera content resulted in a decrease in the use of both soybean and white pollard powders. Feed was shaped in dry pellet form with a size of $1-2 \mathrm{~mm}$.

\section{Rearing during digestibility test stage}

Tilapia with average body weight of $7.00 \pm 1.00$ $\mathrm{g}$ brought the center for freshwater fish research and development in Bogor were used in the present research. Fish were acclimatized to experimental condition i.e. placed into aquariums $\left(60 \times 40 \times 40 \mathrm{~cm}^{3}\right)$ previously filled with $72 \mathrm{~L}$ of water (equipped with aeration system). Ten fish per aquarium were used and fed on test feed at satiation at a feeding rate of three times a day during 21 days. Feces collection started on day 4 of the research after feeding (an hour after feeding) and was performed by mean of a rope and a filtering net in order to gather the feces. The collected feces were then placed in an oven at 40 ${ }^{\circ} \mathrm{C}$ for 12 hours and both chromium and proximat analisis performed.

\section{Rearing during growth test}

Twenty tilapias, at average body weight of $3.41 \pm 0.10 \mathrm{~g}$, were placed in each aquarium $\left(60 \times 40 \times 45 \mathrm{~cm}^{3}\right)$, which represent each treatment. The tested fish were acclimatized to experimental conditions, that were equipped with aerating system, for 7 days. Prior to feeding on experimental diets, a few experimental fish were sampled in order determine not only the intial proximate composition but also the intial weight.

Feeding was done three times a day at satiation i.e. 08.00 a.m., 12.00 a.m., and 4 p.m., and fish

Table 1. Composition and proximate of growth performance test feed supplemented with C. lentillifera for tilapia, for 50 days

\begin{tabular}{lcccc}
\hline \multirow{2}{*}{ Raw materials } & \multicolumn{4}{c}{ C. lentillifera composition in feed } \\
\cline { 2 - 5 } & $0 \%$ & $10 \%$ & $20 \%$ & $30 \%$ \\
\hline Fish meal & 10.00 & 10.00 & 10.00 & 10.00 \\
Soybean meal & 45.00 & 39.70 & 34.40 & 29.20 \\
C. lentillifera powder & 0.00 & 10.00 & 20.00 & 30.00 \\
White pollard powder & 35.04 & 30.34 & 25.51 & 20.60 \\
Tapioca & 3.00 & 3.00 & 3.00 & 3.00 \\
Fish oil & 0.60 & 0.50 & 0.50 & 0.50 \\
Corn oil & 0.00 & 0.20 & 0.43 & 0.64 \\
Palm oil & 3.30 & 3.20 & 3.10 & 3.00 \\
Premix & 2.00 & 2.00 & 2.00 & 2.00 \\
Di-Calsium-Phospat & 1.00 & 1.00 & 1.00 & 1.00 \\
Vitamin C & 0.06 & 0.06 & 0.06 & 0.06 \\
\hline & 100 & 100 & 100 & 100 \\
\hline Protein & 28.32 & 28.83 & 29.42 & 27.66 \\
Lipid & 5.64 & 5.13 & 5.8 & 5.25 \\
Ash & 11.41 & 12.43 & 13.39 & 14.11 \\
NFE & 48.64 & 47.29 & 44.61 & 45.95 \\
Crude fiber & 5.99 & 6.32 & 6.78 & 7.03 \\
Gross energy (calories/kg) & 4110.3 & 4035.6 & 4021.7 & 3926.4 \\
\hline Not NFE & & & & \\
\hline
\end{tabular}

Note: NFE $=$ nitrogen free extract. Energy conversion calculation followed Watanabe (1988) method, i.e. $1 \mathrm{~g}$ protein $=5.6 \mathrm{kcal} \mathrm{GE}, 1 \mathrm{~g}$ carbohydrate $/ \mathrm{NFE}=4.1 \mathrm{kcal} \mathrm{GE}$, and $1 \mathrm{~g}$ lipid $=9.4 \mathrm{kcal} \mathrm{GE}$. 
were reared for a period of 50 days. Total feed consumption and dead fish were recorded throughout the research period. Water exchange was periodically performed (every morning) and aeration provided (to supply dissolved oxygen) in order to maintain an optimal water quality. The tested fish were sampled at the end of the research to analyse nutritional contents.

Fish were starved for a day at the end of the rearing period and anesthetized using $0.67 \mathrm{mg} / \mathrm{L}$ of cean free special arowana stabilizer. Fish were then weighed and measured to determine growth and proximate analysis (for protein and fat retention).

\section{Chemical analysis}

Chemical analysis consisted of chromium analysis, mineral analysis, and proximate analysis. Chromium analysis of both feed and feces was performed using the spectrophotometric method. Proximate analysis of feed and fish body (initial and final) consisted of water content, protein, crude fiber, ash, and NFE. Water content and ash analysis were performed with the gravimetric method, protein with kjeldhal method, lipid with Soxhlet method, and organic matter with Vansus method. The present proximate analysis was in accordance with AOAC procedure. Mineral content analysis $(\mathrm{Ca}, \mathrm{Mg}$, and $\mathrm{Fe})$ used weight destruction method which was read by Atomic Absorbance Spectrofotometer (AAS).

\section{Tested parameters}

The observed parameters in the present research was $C$. lentillifera digestibility, which resulted from the first series of research based on Watanabe (1988) calculation, and consisted of parameters such as protein, calcium, magnesium, and iron digestibilities. The second series of the present research involved other parameters such as feed consumption (Watanabe, 1988),

Table 2. C. lentillifera powder digestibility in tilapia

\begin{tabular}{lc}
\hline Tested parameters & Digestibility $(\%)$ \\
\hline Total Digestibility & $68.81 \pm 1.2$ \\
Protein digestibility & $86.31 \pm 0.6$ \\
Ca digestibility & $38.49 \pm 1.1$ \\
Mg digestibility & $32.46 \pm 2.3$ \\
Fe digestilibty & $36.21 \pm 0.8$ \\
\hline
\end{tabular}

Note: The value listed above are averages followed by standard deviation. $\mathrm{Ca}=$ calsium. $\mathrm{Mg}=$ magnesium. $\mathrm{Fe}=$ iron. protein efficiency ratio (Watanabe, 1988), protein retention (Watanabe, 1988), lipid retention (Watanabe, 1988), specific growth rate (Halver, 1989), feed efficiency (Watanabe, 1988), survival rate (Effendi, 2004), and absolute growth rate of tilapia (Watanabe, 1988).

\section{Data analysis}

Data were analyzed using independent-test analysis of variance (ANNOVA) with an interval of confidence of $95 \%$, using SPSS 21.00 , followed by a Duncan-test if significant differences were observed.

\section{RESULTS AND DISCUSSION}

\section{Results}

Digestibility test results of $C$. lentillifera powder is presented in Table 3. Results showed a total $C$. lentillifera digestibility of $68.81 \%$ with a protein digestibility of $86.31 \%$. C. lentillifera powder had a high mineral content, including calcium, magnesium, and iron with digestibilities of $3.49 \%, 32.46 \%$, and $36.21 \%$, respectively.

Table 3 represents growth performance parameters of tilapia fed on different doses of $C$. lentillifera powder with final body weight ranging from 9.28-10.87 $\mathrm{g} \quad(\mathrm{P}>0.05)$. no significant differences $(\mathrm{P}>0.05)$ were observed between treatments in terms of feed consumption during the 50 days rearing period, ranging between 11.20 to $11.95 \mathrm{~g}$. the lowest specific growth rate (SGR) in the $30 \%$ C. lentillifera (2\%), was not significantly different with $20 \% C$. lentillifera $(\mathrm{P}>0.05)$. yet, $\mathrm{SGR}$ in the $10 \% C$. lentillifera, $20 \%$ C. lentillifera, and control did not significantly differ. According to results of the analysis of variance, some parameters, such as protein efficiency ratio, protein retention, and feed efficiency, supported the use of $C$. lentillifera powder as raw material up to $20 \%$ in tilapia feed without being significant different to the control $(\mathrm{P}>0.05)$. there were no significant differences among treatments in terms of survival rate, which ranged from 96.67 to $98.33 \%$.

The body composition of the tested fish at both the beginning and the end of the rearing period is presented in Table 4. The test results showed that both protein and lipid contents of the fish body increased after the rearing period. The use of $C$. lentillifera powder did not significantly $(\mathrm{P}>0.05)$ affect protein, crude fiber and NFE composition of the fish body (final). 
Table 3. Growth performance of tilapia fed on C. lentillifera with different compositions

\begin{tabular}{lcccc}
\hline \multirow{2}{*}{ Parameters } & \multicolumn{4}{c}{ C. lentillifera composition in feed } \\
\cline { 2 - 5 } & $0 \%$ & $10 \%$ & $20 \%$ & $30 \%$ \\
\hline $\mathrm{W}_{0}(\mathrm{~g})$ & $3.41 \pm 0.05 \mathrm{a}$ & $3.41 \pm 0.08 \mathrm{a}$ & $3.41 \pm 0.05 \mathrm{a}$ & $3.41 \pm 0.09 \mathrm{a}$ \\
$\mathrm{W}_{50}(\mathrm{~g})$ & $10.81 \pm 0.65 \mathrm{a}$ & $10.87 \pm 0.37 \mathrm{a}$ & $9.84 \pm 0.82 \mathrm{ab}$ & $9.28 \pm 0.34 \mathrm{~b}$ \\
$\mathrm{AGR}(\mathrm{g})$ & $7.40 \pm 0.65 \mathrm{a}$ & $7.47 \pm 0.36 \mathrm{a}$ & $6.43 \pm 0.82 \mathrm{ab}$ & $5.88 \pm 0.34 \mathrm{~b}$ \\
TFC (g) & $11.95 \pm 0.46 \mathrm{a}$ & $11.72 \pm 0.68 \mathrm{a}$ & $11.20 \pm 0.89 \mathrm{a}$ & $11.24 \pm 0.36 \mathrm{a}$ \\
PER (\%) & $2.19 \pm 0.17 \mathrm{a}$ & $2.21 \pm 0.05 \mathrm{a}$ & $1.95 \pm 0.13 \mathrm{ab}$ & $1.89 \pm 0.09 \mathrm{~b}$ \\
PR (\%) & $28.82 \pm 2.04 \mathrm{a}$ & $29.10 \pm 1.27 \mathrm{a}$ & $26.77 \pm 3.21 \mathrm{a}$ & $26.17 \pm 3.05 \mathrm{a}$ \\
LR (\%) & $70.67 \pm 4.01 \mathrm{a}$ & $61.61 \pm 1.64 \mathrm{~b}$ & $61.12 \pm 2.73 \mathrm{~b}$ & $52.94 \pm 2.01 \mathrm{c}$ \\
SGR (\%/day) & $2.31 \pm 0.12 \mathrm{a}$ & $2.32 \pm 0.07 \mathrm{a}$ & $2.12 \pm 0.16 \mathrm{ab}$ & $2.00 \pm 0.07 \mathrm{~b}$ \\
FE (\%) & $61.92 \pm 4.72 \mathrm{a}$ & $63.71 \pm 1.41 \mathrm{a}$ & $57.32 \pm 3.88 \mathrm{a}$ & $52.28 \pm 2.62 \mathrm{~b}$ \\
SR (\%) & $96.67 \pm 5.77 \mathrm{a}$ & $98.33 \pm 2.89 \mathrm{a}$ & $98.33 \pm 2.89 \mathrm{a}$ & $98.33 \pm 2.89 \mathrm{a}$ \\
\hline
\end{tabular}

Note: The value listed above are averages followed by standard deviation. Different letters behind the standard deviations showed significant differences between treatments $(\mathrm{P}<0.05) . \mathrm{W} 0=$ initial individual body weight; W50 = individual final body weight; AGR: absolute growth rate; $\mathrm{SR}=$ survival rate; $\mathrm{TFC}=$ total feed consumption; $\mathrm{PER}=$ protein efficiency ratio; $\mathrm{PR}=$ protein retention; $\mathrm{LR}=$ lipid retention; $\mathrm{SGR}=$ specific growth rate; $\mathrm{FE}=$ feed efficiency.

\section{Discussion}

Digestibility shows the composition of nutrients (amount) that are digested and used for growth and metabolic processes (NRC, 2011). The results (Table 2) in the present study revealved that tilapia has the ability to digest $C$. lentillifera powder up to $68.81 \%$, which was a little bit higher compared to the digestibility of Ulva lactuca powder, being 66.26\% (Mahasu, 2016).

C. lentillifera powder had a protein digestibility value of $86.26 \%$ (Table 2), which was within the normal range for optimal digestible protein in fish feed. The optimal value of digestible protein of a given raw material in fish feed ranged from 75 to 95\% (NRC, 2011). The protein digestibility of $C$. lentillifera powder was not significantly different compared to those of white pollard $(83.87 \%)$, soybean meal $(91.12 \%)$, and fish meal (83.53\%) (Ribeiro et al., 2011).

Minerals and vitamins are micro-nutruients needed in fish feed. Most of the seaweeds have high mineral contents (Kut-Guroy, 2007; Matanjun et al., 2009; Natify et al., 2015; Mahasu, 2016), and in the proximate analysis scheme, a few minerals were classified as ash, including calcium and magnesium. The micro-mineral with a high content in seaweeds is iron (Matanjun et al., 2009). According to Sugiura et al. (1998), a high ash consumption through feed will result in a decrease in nutrient absorption. The digestibility of three minerals in $C$. lentillifera powder were observed in the present study i.e. calcium, magnesium, and iron. Calcium is a micromineral that has a high content in $C$. lentillifera seaweed (Matanjun et al., 2009) and plays an important role in fish growth with a digestibility (in $C$. lentillifera) of $38.49 \%$. In addition to calcium, magnesium and iron had digestibility of $32.46 \%$ and $36.21 \%$, respectively, in the present study (Table 2). The nutrients digestibility of $C$. lentillifera powder showed interesting values as raw material for tilapia feed. In calculating the nutritional requirement to determine the best feed composition, the present study used $0,10,20$, and $30 \%$ C. lentillifera powder concentrations in feed.

The survival rate data (Table 3) showed that the use of $C$. lentillifera powder up to $30 \% \operatorname{did}$ not negatively affect growth and water quality, which was optimum for tilapia culture. The variations in the results are consequences of the given treatments i.e. the use of various $C$. lentillifera powder composition in tilapia feed.

Growth performance parameters, other than the body weight, were also supported by factors such as feed consumption, protein efficiency ratio, lipid and protein retentions, daily growth rate and feed efficiency (Table 3). The total feed, that suits the stomach capacity or the period of time when fish need feed, has to be considered due to the fact that at a time fish is close to hunger (Sunarno, 1991). The amount of feed consumed showed that the difference in $C$. lentillifera powder composition in feed does not affect the palatability of tilapia and also the fish appetite.

The protein efficiency reveals the ratio of fish body weight and the protein of the consumed feed. Based on feed efficiency ratio results, the 
Table 4. Fish body composition at the beginning and the end of the rearing period (\% of dry weight)

\begin{tabular}{lccccc}
\hline \multirow{2}{*}{ Tested parameters (\%) } & \multirow{2}{*}{ Initial } & \multicolumn{4}{c}{ C. lentillifera composition in the feed } \\
\cline { 3 - 6 } & & $0 \%$ & $10 \%$ & $20 \%$ & $30 \%$ \\
\hline Water content & 77.6 & $75.33 \pm 1.31 \mathrm{a}$ & $72.31 \pm 1.18 \mathrm{~b}$ & $75.24 \pm 1.28 \mathrm{a}$ & $74.63 \pm 0.89 \mathrm{a}$ \\
Ash content & 27.55 & $15.48 \pm 1.83 \mathrm{a}$ & $16.81 \pm 0.53 \mathrm{ab}$ & $17.33 \pm 0.76 \mathrm{ab}$ & $17.83 \pm 0.32 \mathrm{~b}$ \\
Protein & 46.75 & $48.41 \pm 1.53 \mathrm{a}$ & $51.48 \pm 2.06 \mathrm{a}$ & $49.34 \pm 0.96 \mathrm{a}$ & $48.39 \pm 1.62 \mathrm{a}$ \\
Lipid & 4.97 & $18.29 \pm 0.49 \mathrm{a}$ & $17.22 \pm 0.25 \mathrm{~b}$ & $17.21 \pm 0.41 \mathrm{~b}$ & $15.31 \pm 0.51 \mathrm{c}$ \\
Crude fiber & 1.67 & $1.78 \pm 0.53 \mathrm{a}$ & $2.19 \pm 0.28 \mathrm{a}$ & $2.22 \pm 0.25 \mathrm{a}$ & $2.16 \pm 0.20 \mathrm{a}$ \\
NFE & 19.06 & $16.04 \pm 2.24 \mathrm{a}$ & $12.29 \pm 2.10 \mathrm{a}$ & $13.90 \pm 1.88 \mathrm{a}$ & $16.31 \pm 2.39 \mathrm{a}$ \\
\hline
\end{tabular}

Note: Same letters in the same line showed no significant differences among treatments $(\mathrm{P}>0.05)$. The value listed above are averages followed by standard deviation. NFE $=$ free nitrogen extract.

use of $C$. lentillifera powder up to $20 \%$ in tilapia feed had a protein-energy ratio that is in line with tilapia requirement. In addition, Khan and Abidi (2012) stated that the use of protein depends on the availability of non-protein energy source in the feed that will affect the efficiency of nutrient retentiton.

The higher the use of $C$. lentillifera powder in the feed, the lower the lipid retention. The results of the present study showed that a decrease in lipid retention did not lead to an increase in growth. It is believed that the use of carbohydrate as energy source is not efficient due to the use of the lipid stored in the body as energy source.

The maximal use of energy by lipid and carbohydrate can support the use of protein as a component of fish growth. The use of $C$. lentillifera up to $30 \%$ in the feed resulted in the lowest specific growth. The growth of the tested fish can be also determined through the growth of the absolute weight. The growth of tilapia in the $30 \%$ C. lentillifera treatment had the lowest absolute growth compared to other treatments.

The low growth observed in the results of the present research revealed was supported by a low feed efficiency in the $30 \%$ C. lentillifera treatment. The growth was observed to decline as $C$. lentillifera powder increased in tilpia feed, which was a consequence of high crude fiber and ash contents in the challenge feed (Table 1). Feed fiber will remain in the digestive tract for a short period of time causing a decrease in feed nutrient absorption (Fitriliyani, 2010), since a high crude fiber content in feed can decline feed nutrient absorption. In addition, Sugiura et al. (1998) stated that high ash consumption in feed will lead to a decrease in nutrient absorption that will finally result in a decrease in growth. Other identification included anti-nutritional subtances in algae i.e. lectin (Oliveira et al., 2002), which is amother type of toxic proteins that causes agglutination or cultivation of red blood cells. Caulerpa curpressoides was observed to have a high lectin content in the forms of glycine, aspartic acid, glutamic acid and serine as well as a low content of basic amino acids (Benevide $e t$ al., 2001).

Pratama et al. (2015) explained in their research that fish needs more feed materials that provide a good combination of essential amino acids. Thus, the formulation of protein profile is of capital importance, since feed protein will be directly used by the fish for both maintenance and growth purposes. The weakness of $C$. lentillifera is that it has a low essential amino acids content such as methionine and lysine (Matanjun et al., 2009). Methionine is very important for growth and a decrease in methionine will lead to a slow growth of the fish (Hu et al., 2013). Based on the essential amino acids composition determination (Figure 1) from feed raw materials references (Matanjun et al., 2009; NRC, 2011), lysine content of the $30 \%$ C. lentillifera treatment was lower compared to Tilapia requirement. A low lysine content can lead to an imbalance of the amino acids. Lysine helps in calcium absorption that is needed for bone formation (Li et al., 2008). Figure 1 revealed that a lower threonine content compared to tilapia requirement in both $20 \%$ and $30 \%$ C. lentillifera treatments. That was in line with the results of Yue et al. (2014) research, which proved that threonine induction in feed will result in a reduced growth in tilapia without any pathological symptoms. Similar results were also observed in Indian catfish (Ahmed, 2007) and Indian major carp (Abidin \& Khan 2008). Special attention need to be paid to the amino acids balance in feed, since an imbalance in type of composition can affect protein synthesis efficiency, resulting in not only in a low protein retention, but also a low 


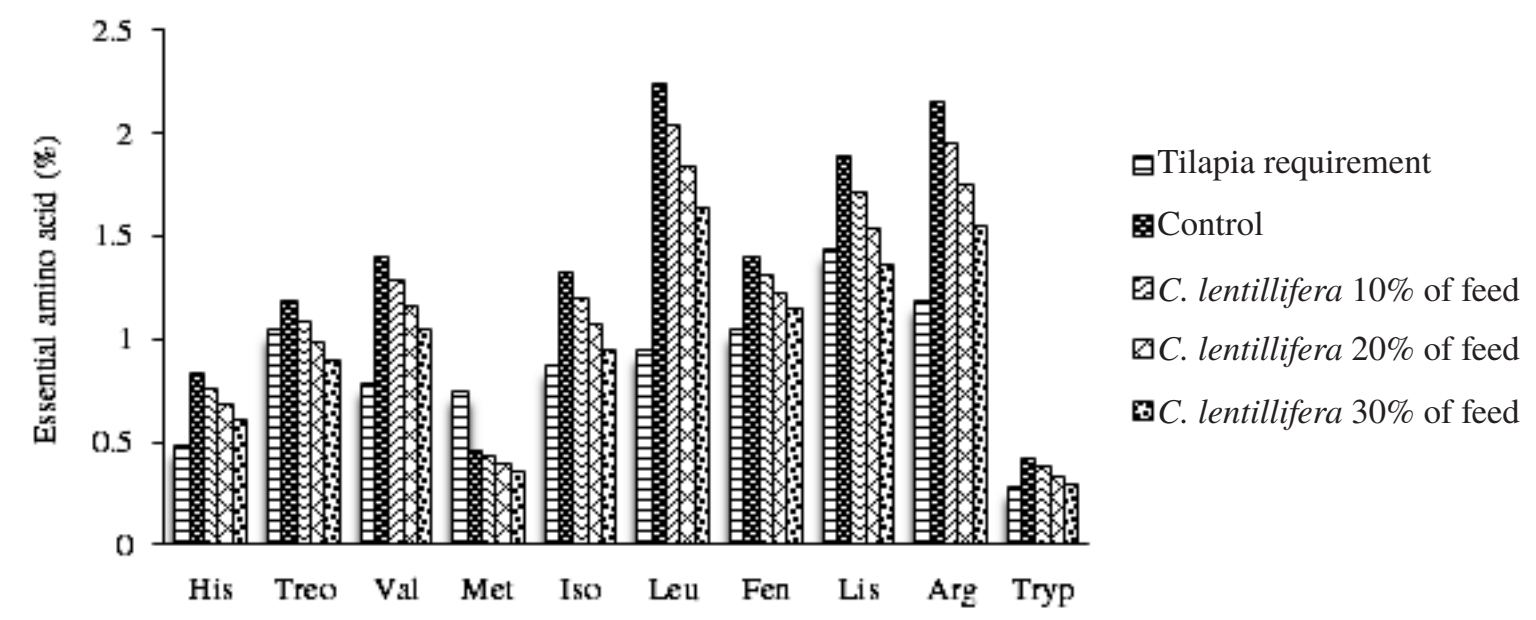

Figure 1. Essential amino acis pronle of tilapia requirement and test teed with C. lentillifera (Matanjun et al., 2009; NRC, 2011).

growth (Conde-Aguilera et al., 2013; Hu et al., 2013; Valverde et al., 2013), which was probably the case in the $30 \%$ C. lentillifera treatment.

Chemical composition of the fish body postrearing period showed an increase in both protein and fat contents compared to that of the fish before the experiment (Table 4). The increment of protein composition in fish body (final) that did not differ in the use of $C$. lentillifera up to $20 \%$ was supported by protein retention values in each treatment. Similar results were observed in the use of Ulva seaweed, which is a green alga, as raw material for fish feed that did not significantly differ in terms of body protein composition (KutGuroy et al., 2007; Diler et al., 2007; Natify et al., 2015; Mahasu, 2016). A difference case was observed with the lipid in fish body after rearing and sisgnificant differences were observed in terms of C. lentillifera addition in tilapia feed. The higher $C$. lentillifera content of the feed, the lower the lipid content of the fish body, which was supported by lipid retention values in each treatment. Diler et al. (2007) reported that the use of Ulva up to $20 \%$ can decrease the lipid contained in common carp body. A high protein and a low lipid in $C$. lentillifera treatments (up to $20 \%$ ) are believed to be a consequence of the feed having a balanced of protein and non-protein that fulifill fish requirements, since lipid can be efficiently used as energy leading to a low lipid storage in fish body.

\section{CONCLUSION}

C. lentillifera powder has a good digestibility value for fish and can be used up to $20 \%$ in fish feed, making it eligible as raw material for tilapia Oreochromis niloticus feed.

\section{ACKNOWLEGEMENT}

We would like to thank not only the head of fishery research center but also the research teams in both nutrition and development laboratories (of the center for freshwater fish development, Bogor) for their helps and supports.

\section{REFERENCES}

[GPMT] Gabungan Pengusaha Makanan Ternak. 2015. Data produksi dan distribusi pakan. Indonesian Feedmills Association, http:// www.asosiasi-gpmt.blogspot.co.id/p/dataproduksi-pakan.html. [1 September 2016].

[NRC] National Research Council. 2011. Nutrient Requirements of Fishes. Washington DC (US): National Academy of Sciences.

Abidin SF, Khan MA. 2008. Dietary threonine requirement of fingerling Indian major carp, Labeo rohita (Hamilton). Aquaculture Research 39: 1498-1505.

Ahmed I. 2007. Dietary amino acid L-threonine requirement of fingerling Indian catfish, Heteropneustes fossilis (Bloch) estimated by growth and biochemical parameters. Aquaculture International 15: 337-350.

Afebrata DR, Santoso L, Suparmono. 2014. Substitusi tepung onggok singkong sebagai bahan baku pakan pada budidaya ikan nila Oreochromis nilotius. Jurnal Rekayasa dan Teknologi Budidaya Perairan 2: 233-240.

Chaitanawisuti N, Santhaweesuk W, Kristsanapuntu S. 2011. Performance of the seaweed Gracilaria salicornia and Caulerpa lentillifera as biofilters in hatchery scale recirculating aquaculture system for juvenile spotted babylons Babylonia areolata. Journal 
Aquaculture International 19: 1139-1150.

Conde-Aguilera JA, Cobo-Ortega C, Tesseraud S, Lessire M, Mercier Y, Van Milgen J. 2013. Changes in body composition in broilers by a sulfur amino acid deficiency during growth. Poultry Science 92: 1.266-1.275.

Diler I, Tekinay AA, Güroy D, Güroy B, Soyuturk M. 2007. Effects of Ulva rigida on the growth feed intake and body composition of common carp, Cyprinus carpio. Journal of Biological Sciences 7: 305-308.

Fitriliyani I. 2010. Evaluation of the nutritional value of Leucaena leucophala leaf meal hydrolyzed by sheep rumen liquor enzyme extract on the growth performance of Nile tilapia Oreochromis niloticus. Jurnal Akuakultur Indonesia 9: 30-37.

Hu M, Wang Y, Wang Q, Zhao M, Xiong B, Qian X, Zhao Y, Luo Z. 2013. Replacement of fish meal by rendered animal protein ingredients with lysine and methionine supplementation to practical diets for gibel carp Carassius auratus gibelio. Aquaculture 275: 260-265.

Jusadi D, Ekasari J, Kurniansyah A. 2013. Improvement of cocoa-pod husk using sheep rumen liquor for tilapia diet. Jurnal Akuakultur Indonesia 12: 43-51.

Khan MA, Abidi SF. 2012. Effect of varying protein to energy ratios on growth, nutrient retention, somatic indices, and digestive enzyme activities of singhi, Heteropneustes fossilis (Blonch). Journal of the World Aquaculture Society 43: 490-501.

Kut-Guroy K, Cirik S, Guroy D, Sanver F, Tekinay AA. 2007. Effect of Ulva rigida and Cystoseira barbata meals as a feed additive on growth performance, feed utilization and body composition of Nile tilapia Oreochromis niloticus. Turkish Journal of Veterinary Animal Sciences 31: 91-97.

Li P, Mai K, Trushenski J, Wu G. 2008. New developments in fish amino acid nutrition: towards functional and enviromentally oriented aquafeeds. Amino Acids 37: 43-45.

Liu H, Wang F, Wang Q, Dong S, Tian X. 2016. A comparative study of the nutrient uptake and growth capacities of seaweeds Caulerpa lentillifera and Gracilaria lichenoides. Journal of Applied Phycology 28: 3083-3089.

Mahasu, NH. 2016. Evaluation of seaweed Ulva actuca utilization as substitute pollard for sultana tilapia Oreochromis niloticus diets [Thesis]. Bogor: Institut Pertanian Bogor.

Matanjun P, Mohamed S, Mustapha NM,
Kharidah M. 2009. Nutrient content of tropical edible seaweeds, Eucheuma cottonii, Caulerpa lentillifera and Sargassum polycystum. Journal of Applied Phycology 21: 75-80.

Murugaiyan K, Narasimman S, Anatharaman P. 2012. Proximate composition of marine macro algae from Seeniappa Dharka, Gulf of Mannar Region, Tamil Nadu. International Journal of Research in Marine Sciences 1: 1-3.

Natify W, Droussi M, Berday N, Araba A, Benabid M. 2015. Effect of seaweed Ulva lactuca as a feed additive on growth performance, feed utilization and body composition of Nile tilapia Oreochromis niloticus L. International Journal of Agronomy and Agricultural Research 7: 85-92.

Oliveira SRM, Nascimento AE, Lima MEP, Leite YFM, Benevides NMB. 2002. Purification and characterisation of a lectin from the red marine alga Pterocladiella capillacea (S.G. Gmel.) Santel. \& Hommers. Revista Brasileira de Botanica 25: 397-403.

Pratama AP, Rachmawati D, Samidjan I. 2015. The effect of enzyme phytase addition in artificial feed for feed utilization efficiency, growth and survival rate of saline red tilapia Oreochromis niloticus. Journal of Aquaculture Management and Technology 4: 150-158.

Ribeiro FB, Lanna EAT, Bomfim MAD, Donzele JL, Quadros M, Cunha PSL. 2011. True and apparent of protein and amino acids of feed in Nile tilapia. Revista Brasileira de Zootecnia 40: 939-946.

Sahat HJ. 2013. Rumput Laut Indonesia. Indonesia: Jakarta: Warta Ekspor edisi September.

Sugiura SH, Dong FM, Rathbone CK, Hardy RW. 1998. Apparent protein digestibility and mineral availabilities in various feed ingredients for salmonid feeds. Aquaculture 159: 177-202.

Suprayudi MA, Edriani G, Ekasari J. 2012. Quality evaluation of fermented products of various local agroindustrials by-products: the effect on digestibility and growth performance of common carp juvenile. Jurnal Akuakultur Indonesia 2: 1-10.

Valverde, Cerezo J, Martines-Llorens S, Vidal AT, Jover M, Rodriguez C, Estefanell J, Gairin JI, Domingues PM, Rodriguez CJ, Garcia BG. 2013. Amino acid composition and protein quality evaluation of marine species and meals for feed formulations in Cephalopods. Aquaculture International 21: 413-433. 
WatanabeT.1988.Fish Nutrition and Marinculture. Tokyo, Jepang: Department of Aquatic Bioscience. TokyoUniversityofFisheries.JICA. Widyastuti S. 2008. Pengolahan pasca panen alga merah strain lokal Lombok menjadi agar menggunakan beberapa metode ekstraksi. Jurnal Lembaga Penelitian Unram 2: 63-72. Widyastuti S. 2010. Sifat fisik dan kimiawi karagenan yang diekstrak dari rumput laut Eucheuma cottoni dan E. spinosum pada umur panen yang berbeda. Jurnal Agroteksos 20: 41-50.

Yue Y, Zou Z, Jinglin Z, Li D, Xiao W, Han J, Yang H. 2014. Dietary threonine requirement of juvenile Nile tilapia Oreochromis niloticus. Aquaculture International 22:1457-1467. 